CARDIOVASCULAR MEDICINE

\title{
Exercise capacity and cardiac function assessed by tissue Doppler imaging in chronic heart failure
}

\author{
K K A Witte, N P Nikitin, R De Silva, J G F Cleland, A L Clark
}

Heart 2004;90:1144-1150. doi: 10.1136/hrt.2003.025684

\begin{abstract}
Objective: To examine the relation between longitudinal left ventricular function assessed by tissue Doppler imaging (TDi) and exercise capacity in heart failure.

Subjects: 153 patients with chronic heart failure from left ventricular systolic dysfunction (ejection fraction $<45 \%$ ) and 87 age and sex matched controls.

Methods: Echocardiography was used to measure conventional indices of left ventricular systolic function. TDi was used to assess left and right ventricular longitudinal function by measuring mitral and lateral tricuspid annular velocities during the cardiac cycle. Velocities measured at each point were the systolic peak $\left(S_{m}\right)$ and the diastolic troughs $\left(E_{m}\right.$ and $\left.A_{m}\right)$, corresponding to passive and active (atrial) left ventricular filling. Each patient also underwent treadmill exercise testing with metabolic gas exchange measurements.

Results: Left and right ventricular TDi velocities were greater in controls than in patients. Left ventricular ejection fraction (LVEF) correlated with $S_{m}(r=0.30, p=0.0005)$, but not with $E_{m}, A_{m}$, or the $E_{m} / A_{m}$ ratio. There were no significant differences between New York Heart Association (NYHA) functional class for any of the TDi variables. Right ventricular indices were not related to exercise capacity. Systolic myocardial motion measured by TDi correlated more closely with peak oxygen consumption $\left(\mathrm{pVO}_{2}\right)$ $(r=0.35, \mathrm{p}<0.0001)$ than $\operatorname{LVEF}(r=0.21, \mathrm{p}<0.02)$. The $\mathrm{E}_{\mathrm{m}} / \mathrm{A}_{\mathrm{m}}$ ratio was not correlated with $\mathrm{pVO} \mathrm{V}_{2}$. In multiple regression, $S_{m}$ was the only left ventricular TDi variable to predict exercise capacity independently $(p<0.05)$.

Conclusions: Exercise capacity and symptoms are poorly related to conventional measures of cardiac function and more closely correlated with indices of longitudinal left ventricular function as assessed by TDi.
\end{abstract}

See end of article for authors' affiliations

Correspondence to:

Dr K Witte, Academic

Cardiology, Castle Hill

Hospital, Castle Road,

Cottingham, Hull HU16

5JQ, UK; klauswitte@

hotmail.com

Accepted

8 December 2003
$\mathrm{P}$ atients with chronic heart failure complain of exercise intolerance, usually because of breathlessness and fatigue. ' Incremental exercise testing with metabolic gas exchange measurements used to derive peak oxygen consumption $\left(\mathrm{p} \dot{\mathrm{V}}_{2}\right)$ allows an objective assessment of symptoms and exercise capacity. ${ }^{2}$

Generally, resting echocardiographic variables predict exercise capacity poorly in chronic heart failure. Resting left ventricular ejection fraction (LVEF) correlates weakly with exercise capacity ${ }^{3-8}$ and other markers of exercise capacity, such as the slope of the relation between ventilation ( $\left.\dot{V}_{E}\right)$ and carbon dioxide production $\left(\dot{\mathrm{V}} \mathrm{CO}_{2}\right)\left(\dot{\mathrm{V}} \mathrm{E} / \dot{\mathrm{V}}_{\mathrm{CO}_{2}}\right.$ slope $)$. Many patients with reduced exercise capacity have similar global left ventricular function to less limited individuals. ${ }^{9}{ }^{10}$ Diastolic dysfunction very commonly accompanies left ventricular systolic dysfunction and maladaptive left ventricular remodelling ${ }^{11}$ and is also associated, if poorly, with reduced exercise capacity. ${ }^{6}{ }^{12-14}$

Tissue Doppler imaging (TDi) allows quantitative assessment of the motion of the myocardium and is particularly helpful in quantifying ventricular long axis function. ${ }^{15}$ TDi can be used to assess both regional and global left ventricular function. Measuring myocardial velocities gives information about regional ventricular contractility, while, as a consequence of the relative immobility of the cardiac apex, the measurement of mitral annular velocities provides information on longitudinal left ventricular function. Regardless of the site of the measurement, the normal TDi profile has a characteristic appearance, consisting of systolic and diastolic myocardial motion (fig 1). Systolic motion often has two peaks, $S^{\prime}$ and $S_{m}$. $S^{\prime}$ reflects isovolumic contraction, while $S_{m}$ occurs during ejection. Diastolic velocities, seen as troughs, consist of early and late myocardial movement ( $\mathrm{E}_{\mathrm{m}}$ and $\left.\mathrm{A}_{\mathrm{m}}\right)$. These correspond to passive ventricular filling and atrial contraction, as do the E and A waves of transmitral flow. Mitral annular velocities are less preload dependent than conventional Doppler indices of mitral inflow ${ }^{16}$ although the diastolic waveforms are not entirely preload independent. ${ }^{17}$

Tricuspid annular profiles are similar to those from the mitral annulus. Right ventricular $S_{m}$ velocity correlates with right ventricular ejection fraction (RVEF) measured by first pass radionuclide ventriculography in chronic heart failure. ${ }^{18}$

We designed this study to explore the relation between tissue Doppler derived measures of long axis ventricular function and exercise capacity.

\section{METHODS}

We investigated 153 patients ( 130 men, 23 women) referred to a university heart failure clinic, and 87 controls (42 men, 45 women). The controls were age matched individuals chosen at random from the lists of local primary care physicians. Chronic heart failure was defined as the presence of symptoms of fatigue or breathlessness on exertion and a left ventricular ejection fraction on echocardiography of less

Abbreviations: $A$, peak velocity of atrial filling; $A_{m}$, late (atrial) diastolic myocardial motion; DT, deceleration time; $E$, peak velocity of early ventricular filling; $E_{m}$, early diastolic myocardial motion; IVRT, isovolumic relaxation time; LVEDD, left ventricular end diastolic diameter; LVEF, left ventricular ejection fraction; LVESD, left ventricular end systolic diameter; $\mathrm{pVO}{ }_{2}$, peak oxygen consumption; RER, respiratory exchange ratio; RVEF, right ventricular ejection fraction; $S^{\prime}$, early systolic myocardial motion: $\mathrm{S}_{\mathrm{m}}$ late systolic myocardial motion; TDi, tissue Doppler imaging; $\mathrm{V}_{\mathrm{CO}_{2}}$, carbon dioxide production; $\mathrm{V} \mathrm{E}$, expiratory minute volume 


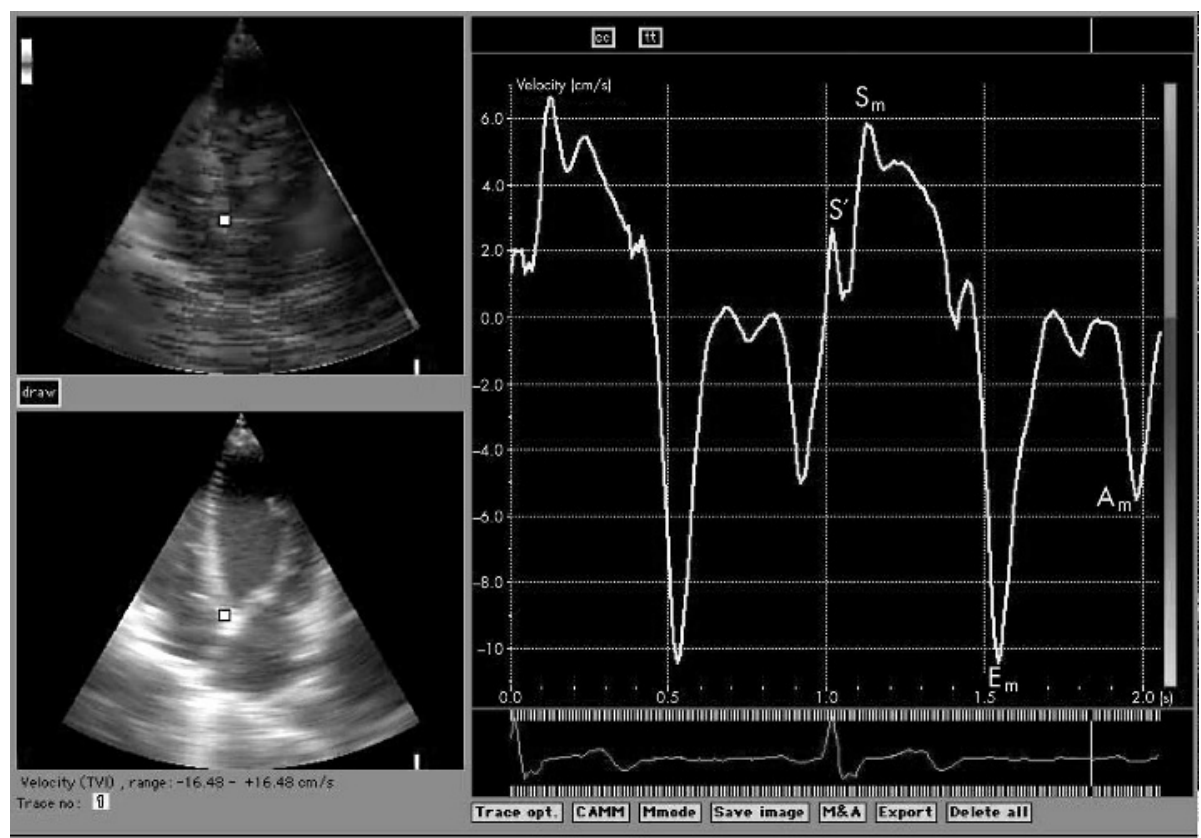

Figure 1 Tissue Doppler imaging (TDi) trace obtained from the mitral annulus. $\mathrm{A}_{\mathrm{m}}$, late (atrial) diastolic myocardial motion; $\mathrm{E}_{\mathrm{m}}$, early diastolic myocardial motion; $S^{\prime}$, early systolic myocardial motion; $\mathrm{S}_{\mathrm{m}}$, late systolic myocardial motion.

than $45 \%$, with no other apparent cause of breathlessness. We did not include patients with neurological conditions or inducible ischaemia on exercise, and for the reliability of the TDi measurements we excluded patients with significant interventricular conduction delay (left bundle branch block).

Informed written consent was obtained in all the study subjects, and the study was approved by the local research ethics committee.

\section{Echocardiography}

Each patient underwent echocardiographic examination including colour B mode TDi (GE Vingmed Vivid Five scanner equipped with $2.5 \mathrm{MHz}$ phased array transducers). All Doppler echocardiographic recordings were obtained during normal respiration.

Left ventricular end diastolic diameter (LVEDD), left ventricular end systolic diameter (LVESD), and interventricular septal and left ventricular posterior wall thickness at end diastole were measured from parasternal $M$ mode echocardiography of the left ventricle. Left ventricular end diastolic volume and end systolic volumes were calculated using the modified Simpson's rule (biplane), and the standard formula was applied to give the left ventricular ejection fraction. Left ventricular end diastolic and end systolic volume indices were obtained by correcting for body surface area.

\section{Doppler echocardiography}

Pulsed wave Doppler studies were done using apical views. Recordings of mitral flow velocities were made from an apical four chamber view with the sample volume positioned adjacent to the tip of either mitral or tricuspid leaflets in diastole. Care was taken to obtain the smallest possible angle between the direction of transvalvar flow and the ultrasound beam.

Peak velocity of early filling (E), peak velocity of atrial filling (A), and the E/A ratio were calculated for both transmitral and transtricuspid flow, and deceleration time (DT) of early filling and isovolumic relaxation time (IVRT) were measured from the transmitral Doppler spectrum. DT was calculated as the time between peak E wave and the upper deceleration slope extrapolated to the baseline, and
IVRT was measured by placing the sample volume between the anterior mitral leaflet and left ventricular outflow tract.

\section{Colour tissue Doppler imaging}

Real time colour tissue Doppler images obtained in three apical views (four chamber, two chamber, and apical long axis view) were stored in digital format. Tissue Doppler data were reviewed off-line with a software analysis system (Echopac 6.3, GE Vingmed).

For the assessment of left ventricular longitudinal function, velocities were measured at the lateral, septal, anterior, inferior, posterior, and antero-septal sites of the mitral annulus in the above views. Right ventricular longitudinal function was assessed by measuring velocities at the lateral site of the tricuspid annulus.

The off-line analysis included measurements of peak systolic velocities $\left(S_{m}\right)$ (ignoring the initial peak $S^{\prime}$ ), and early diastolic $\left(\mathrm{E}_{\mathrm{m}}\right)$ and late diastolic $\left(\mathrm{A}_{\mathrm{m}}\right)$ annular velocities. The values at the six points of the mitral annulus were then averaged and the $E_{m} / A_{m}$ ratio calculated. Figure l shows a representative trace from the septal point of the mitral annulus in the four chamber view. All measurements were done as the mean of two or three consecutive cardiac cycles.

\section{Exercise testing}

Each patient underwent symptom limited, treadmill based, maximal exercise testing using a Bruce protocol modified by the addition of a "stage 0 " at onset, consisting of three minutes of exercise at $1.61 \mathrm{~km} / \mathrm{h}$ (1 mile/hour) with a $5 \%$ gradient. Participants were encouraged to exercise to exhaustion. During the tests patients wore a tightly fitting facemask to which was connected a capnograph and a sample tube enabling on-line ventilation and metabolic gas exchange measurements (Jaeger Oxycon Delta, Würtzburg, Germany). A respiratory exchange ratio (RER; $\dot{\mathrm{V}} \mathrm{CO}_{2} / \dot{\mathrm{V}}_{2}$ ) greater than $\mathrm{l}$ was taken to indicate maximal effort. Standard spirometry (forced expiratory volume in one second $\left(\mathrm{FEV}_{1}\right)$ and forced vital capacity $\left.(\mathrm{FVC})\right)$ was undertaken before the exercise test. The subjects were asked to score their symptoms of breathlessness or fatigue between 0 and $10(0$ being no symptoms and 10 being maximal) on a standard scale of perceived exertion ${ }^{19}$ at the end of each stage during the test. 


\section{Statistical analysis}

Results are presented as mean (SD). There were only two patients each in New York Heart Association (NYHA) functional class I and class IV and these were combined with class II and III, respectively. Unpaired Student's $t$ tests were used to compare the two remaining NYHA groups, the patients versus the controls, and the differences between patients with atrial fibrillation (AF) and sinus rhythm (SR), and to examine differences in the standard deviations in patients with ischaemic and non-ischaemic aetiologies. We also used multiple regression to determine the relative importance of each TDi variable in exercise intolerance in the patient group. Relations between variables were assessed by linear regression. A probability value of $\mathrm{p}<0.05$ was considered significant.

\section{RESULTS}

\section{Basic echocardiographic data}

Subject characteristics and exercise test data are shown in table 1 . The patients had a reduced LVEF and $\mathrm{pV}_{\mathrm{V}_{2}}$ and a greater ventilatory response to exercise ( $\dot{\mathrm{V}} \mathrm{E} / \dot{\mathrm{V}}_{\mathrm{CO}}$ slope) than the controls. In the controls, the $\mathrm{E}$ wave, A wave, and E/A ratio were significantly correlated with age $(r=-0.32$, $\mathrm{p}<0.05 ; r=0.39$, $\mathrm{p}<0.01$; and $r=-0.55$, $\mathrm{p}<0.0001$, respectively), but there was no correlation between left ventricular volumes and ejection fraction and age. In the patient group, there was a weak correlation between age and EDV and ESV $(r=0.18, \mathrm{p}<0.05$, and $r=0.18, \mathrm{p}<0.05)$, but age did not correlate with ejection fraction or Doppler measures of left ventricular diastolic function (E, A, E/A ratio, IVRT, DT). There was also no link between age and NYHA symptom scores. Transmitral flow was also unrelated to diuretic dose or other medical treatment. LVEF and EDV did not correlate with E, A, or DT.

Figure 2 shows LVEF, E, and A wave velocities and E/A ratio split by higher and lower NYHA class. Only the E/A ratio was significantly different between NYHA classes.

In the patients, $p \dot{\mathrm{V}}_{2}$ correlated inversely with $\dot{\mathrm{V}} \mathrm{E} / \dot{\mathrm{V}}_{\mathrm{CO}}$ slope $(r=-0.52, \mathrm{p}<0.0001)$, and age also correlated inversely with $\mathrm{p}_{\mathrm{V}} \mathrm{O}_{2},(r=-0.30, \mathrm{p}<0.0005)$. There was a negative correlation between $\mathrm{pV}_{2}$ and LVEF $(r=-0.2 \mathrm{l}$, $\mathrm{p}<0.02$ ). There were weak correlations with conventional indices of left ventricular diastolic function, $\mathrm{E}$ wave velocity $(r=-0.22, \mathrm{p}<0.01)$, DT $(r=0.17, \mathrm{p}<0.05)$, and E/A ratio $(r=-0.20, \mathrm{p}<0.05)$, but not with A wave velocity (fig 3).

\section{Tissue Doppler data}

The reproducibility of tissue Doppler measurements from our laboratory and the fact that they are more reproducible than LVEF has been reported recently. ${ }^{20}$ Table 2 shows the variables obtained from TDi of the left and right ventricles for patients and controls. Left and right ventricular TDi velocities were significantly lower in the patient group. In patients, there was a negative correlation between age and $\mathrm{E}_{\mathrm{m}} \quad(r=-0.21, \mathrm{p}<0.02)$. There were no significant differences between NYHA classes. Average peak systolic velocity (of three beats) was greater in patients in sinus rhythm than those in atrial fibrillation $(2.89 \vee 2.49$; $\mathrm{p}<0.05$ ), although the standard deviations of the six data points were not different. $\mathrm{E}_{\mathrm{m}}$ was greater in patients with atrial fibrillation $(4.41 \vee 2.82 ; \mathrm{p}<0.0001)$ than in patients in sinus rhythm, and the standard deviation of $\mathrm{E}_{\mathrm{m}}$ measurements was greater in those with atrial fibrillation $(1.56 \mathrm{v}$ 1.18; $\mathrm{p}<0.005)$.

Average peak systolic velocity was greater in subjects with non-ischaemic aetiology than those with ischaemic heart disease $(3.43 \vee 2.62 ; \mathrm{p}<0.002)$, and the standard deviation of the six velocities used to calculate peak $S_{2}$ was lower in those with a non-ischaemic aetiology $(0.80 v 1.04 ; \mathrm{p}<0.05)$. There was no difference in average $\mathrm{E}_{\mathrm{m}}$ or $\mathrm{A}_{\mathrm{m}}$ or their standard deviations between subjects with ischaemic heart disease and those without.

Table 3 shows the relation between the TDi variables and $\mathrm{p} \dot{\mathrm{V}} \mathrm{O}_{2}$ and the $\dot{\mathrm{V}} \mathrm{E} / \dot{\mathrm{V}}_{\mathrm{CO}_{2}}$ slope. In the patient group, systolic and diastolic TDi values were related to $\mathrm{pV}_{\mathrm{O}_{2}}: \mathrm{S}_{\mathrm{m}}(r=0.35$, $\mathrm{p}<0.0001), \mathrm{E}_{\mathrm{m}} \quad(0.20, \mathrm{p}<0.05)$, and $\mathrm{A}_{\mathrm{m}} \quad(r=0.23$, $\mathrm{p}<0.02$ ) (fig 4). The $\mathrm{E}_{\mathrm{m}} / \mathrm{A}_{\mathrm{m}}$ ratio did not correlate with $\mathrm{p}^{\mathrm{V}} \mathrm{O}_{2}$. LVEF correlated with $\mathrm{S}_{\mathrm{m}}(r=0.30, \mathrm{p}=0.0005)$ but not with $E_{m}, A_{m}$, or the $E_{m} / A_{m}$ ratio. Within the patient group, in multiple regression with LVEF, $\mathrm{S}_{\mathrm{m}}, \mathrm{E}_{\mathrm{m}}, \mathrm{A}_{\mathrm{m}}$, and $\mathrm{E}_{\mathrm{m}} / \mathrm{A}_{\mathrm{m}}$ ratio, $\mathrm{S}_{\mathrm{m}}$ was the only variable independently related to $\mathrm{pV}_{\mathrm{O}}(\mathrm{p}<0.05)$.

Age was not related to indices of right ventricular diastolic function such as $E_{m}$ and $A_{m}$ or the $E_{m} / A_{m}$ ratio. There were no differences between NYHA class. Right ventricular indices were not related to exercise capacity.

\begin{tabular}{|c|c|c|c|}
\hline Variable & Patients $(n=153)$ & Controls ( $n=87$ ) & $\mathrm{p}$ Value \\
\hline Age (years) & $66(11)$ & 66 (11) & 0.52 \\
\hline Height $(\mathrm{cm})$ & $172(8)$ & $170(10)$ & 0.31 \\
\hline Weight $(\mathrm{kg})$ & $80.0(15.2)$ & $74.2(11.1)$ & 0.04 \\
\hline Body surface area $\left(\mathrm{kg} / \mathrm{m}^{2}\right)$ & $1.9(0.2)$ & $1.8(0.4)$ & 0.40 \\
\hline Rhythm (SR/AF) & $104 / 49$ & $87 / 0$ & \\
\hline Drugs & & N/A & \\
\hline Frusemide (furosemide) ${ }^{*}$ & $64.4(26.2)$ & & \\
\hline ACEi/AllA (\%) & & & \\
\hline Spironolactone (\%) & 22 & & \\
\hline$\beta$ Blocker (\%) & 44 & & \\
\hline NYHA class I/III/III/IV (n) & $2 / 99 / 48 / 2$ & & \\
\hline LVEF (\%) & $34.9(6.3)$ & $60.5(6.4)$ & $<0.0001$ \\
\hline LVEDV (ml) & $227(72)$ & $99(24)$ & $<0.0001$ \\
\hline LVESV (ml) & $150(59)$ & $39(12)$ & $<0.0001$ \\
\hline Exercise time (s) & 491 (212) & $818(189)$ & $<0.0001$ \\
\hline $\mathrm{pVO}_{2}(\mathrm{ml} / \mathrm{kg} / \mathrm{min})$ & $21.6(5.6)$ & $35.2(7.5)$ & $<0.0001$ \\
\hline $\mathrm{V} \mathrm{E} / \mathrm{VCO}_{2}$ slope & $35.7(8.1)$ & $27.0(2.8)$ & $<0.0001$ \\
\hline \multicolumn{4}{|c|}{ 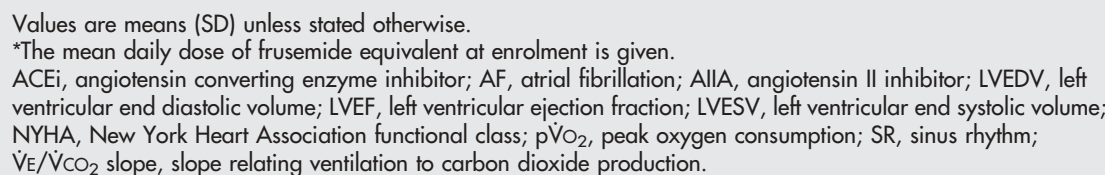 } \\
\hline
\end{tabular}



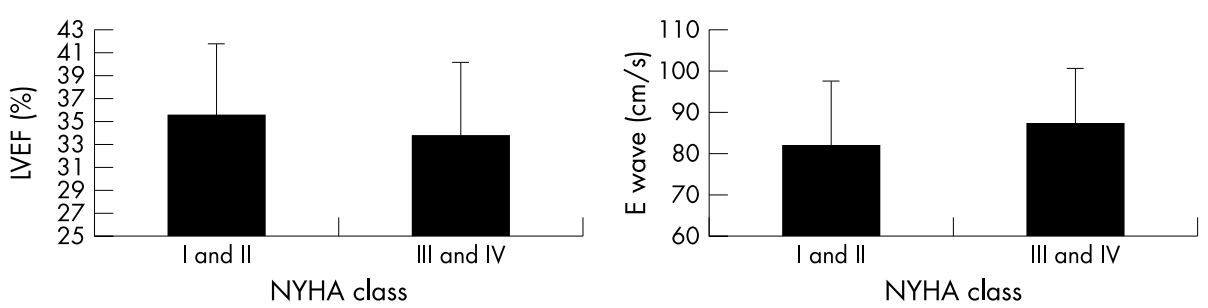

Figure 2 The relation between symptoms and conventional systolic and diastolic indices of left ventricular function.
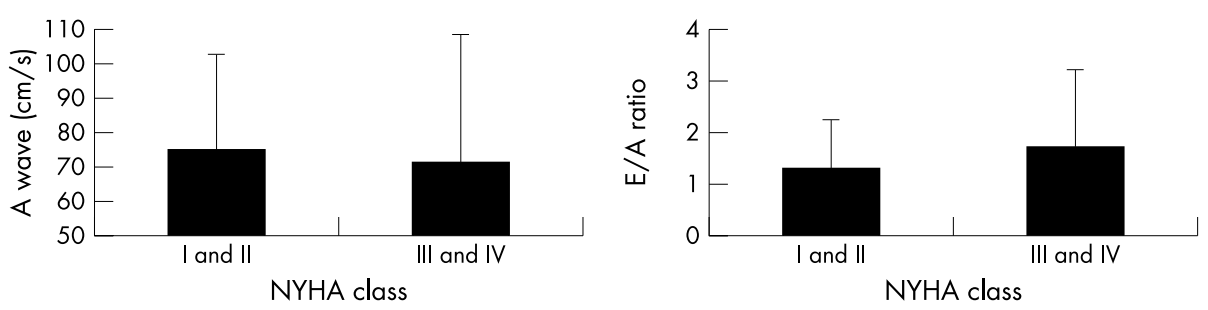

\section{DISCUSSION}

We have shown that indices of resting longitudinal systolic function of the left ventricle are more closely related to peak oxygen consumption than to left ventricular ejection fraction. Conventional measures of left ventricular function such as resting ejection fraction are poorly linked to symptoms and exercise capacity. ${ }^{3-8}$ The closer relation of longitudinal function to exercise capacity might simply be a consequence of the improved accuracy of longitudinal measures in assessing left ventricular systolic function. However, as with left ventricular ejection fraction, TDi measures of long axis function are not closely associated with NYHA symptom scores.

Longitudinal ventricular function is currently assessed using $\mathrm{M}$ mode and tissue Doppler imaging. Mitral annular displacement correlates well with left ventricular ejection fraction measured with B mode echocardiography, ${ }^{21}{ }^{22}$ contrast ventriculography, ${ }^{23}$ and radionuclide ventriculography. ${ }^{24}{ }^{25}$ This correlation is logarithmic rather than linear. ${ }^{26}$ Unlike M mode echocardiography, TDi can be used to calculate both the amplitude and the velocity of mitral annular motion and reliably reflects changes in cardiac contractility, ejection fraction, ejection time and pressures, and "latent" left ventricular dysfunction. . $^{27-34}$

TDi has good reproducibility ${ }^{35}$ and may identify left ventricular dysfunction before conventional indices are abnormal. ${ }^{36}$ Although TDi measures of systolic function are related to traditional measures of left ventricular systolic function such as ejection fraction, TDi might represent a more sensitive method of determining global left ventricular function than traditional indices. ${ }^{37-39}$ Systolic longitudinal function is represented by the second systolic wave $\left(S_{2}\right)$ and diastolic function by $\mathrm{E}_{\mathrm{m}}$ and $\mathrm{A}_{\mathrm{m}}$, the two phases of activity corresponding to passive ventricular filling and atrial contraction, respectively. Normal ranges of these indices obtained with colour coded TDi have recently been established. ${ }^{20}$

In myocardial hypertrophy or ischaemia, longitudinal myocardial function may be impaired earlier than circular fibre activity. ${ }^{37}{ }^{39}$ It is possible that the development of chronic heart failure and impaired ventricular function in patients with relatively well preserved overall LVEF but with
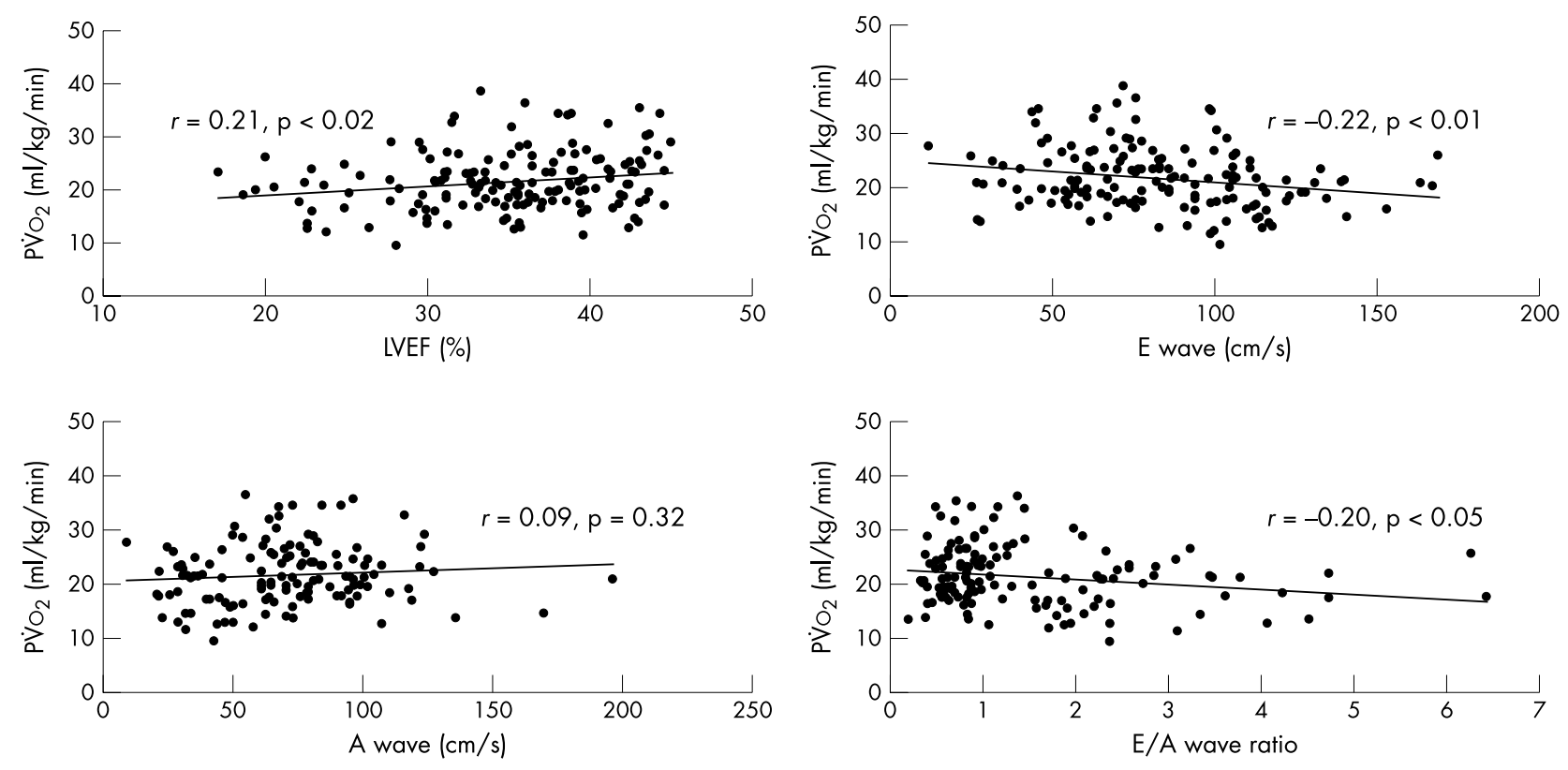

Figure 3 The relation between peak oxygen consumption and conventional systolic and diastolic indices of left ventricular function. 
Table 2 Echocardiographic data for left and right ventricles

\begin{tabular}{|c|c|c|c|}
\hline Variable & Patients $(n=153$ ) & Controls $(n=87$ ) & p Value \\
\hline E wave $(\mathrm{cm} / \mathrm{s})$ & $82.8(30.6)$ & $72.6(15.4)$ & $<0.0005$ \\
\hline A wave $(\mathrm{cm} / \mathrm{s})$ & $71.2(30.7)$ & $70.6(18.2)$ & 0.50 \\
\hline $\mathrm{E} / \mathrm{A}$ ratio & $1.49(1.19)$ & $1.10(0.40)$ & $<0.002$ \\
\hline DT $(\mathrm{ms})$ & $178(67)$ & $227(51)$ & $<0.0001$ \\
\hline \multicolumn{4}{|l|}{ Left ventricle } \\
\hline $\mathrm{S}_{\mathrm{m}}(\mathrm{cm} / \mathrm{s})$ & $2.9(1.2)$ & $5.3(1.3)$ & $<0.0001$ \\
\hline $\mathrm{E}_{\mathrm{m}}(\mathrm{cm} / \mathrm{s})$ & $3.3(1.6)$ & $5.4(2.4)$ & $<0.0001$ \\
\hline$A_{m}(\mathrm{~cm} / \mathrm{s})$ & $4.2(2.0)$ & $6.8(2.4)$ & $<0.0001$ \\
\hline$E_{m} / A_{m}$ & $1.0(1.1)$ & $0.9(0.5)$ & 0.30 \\
\hline$E / E_{m}$ & $30.6(18.2)$ & $15.0(6.3)$ & $<0.0001$ \\
\hline $\mathrm{A} / \mathrm{A}_{\mathrm{m}}$ & $21.4(17.6)$ & $11.7(3.5)$ & $<0.0001$ \\
\hline \multicolumn{4}{|l|}{ Right ventricle } \\
\hline $\mathrm{S}_{2}(\mathrm{~cm} / \mathrm{s})$ & $6.5(2.5)$ & $9.1(2.4)$ & $<0.0001$ \\
\hline $\mathrm{E}_{\mathrm{m}}(\mathrm{cm} / \mathrm{s})$ & $5.2(3.0)$ & $6.8(3.1)$ & $<0.0001$ \\
\hline$A_{m}(\mathrm{~cm} / \mathrm{s})$ & $8.0(3.5)$ & $9.0(3.1)$ & $<0.02$ \\
\hline$E_{m} / A_{m}$ & $0.9(0.8)$ & $0.7(0.8)$ & $<0.05$ \\
\hline$E / E_{m}$ & $13.6(11.6)$ & $10.3(8.1)$ & $<0.02$ \\
\hline $\mathrm{A} / \mathrm{A}_{\mathrm{m}}$ & $7.6(7.8)$ & $5.2(2.7)$ & $<0.005$ \\
\hline $\begin{array}{l}\text { Values are mea } \\
\text { A, peak velocity } \\
\text { ventricular filling } \\
\text { tissue Doppler ir }\end{array}$ & $\begin{array}{l}\text { ng; } A_{m} \text { atrial dias } \\
\text { diastolic TDi wave }\end{array}$ & $\begin{array}{l}\text { ave; DT, decelerat } \\
\text { systolic myocardic }\end{array}$ & $\begin{array}{l}\text { wave, peak velocity of early } \\
\text { 2, late systolic wave; TDi, }\end{array}$ \\
\hline
\end{tabular}

mild to moderate exercise intolerance is therefore identified earlier by TDi. This would increase the correlation between the measures of cardiac function and exercise capacity.

Mitral annular $\mathrm{E}_{\mathrm{m}}$ velocity reflects the diastolic properties of the left ventricle and is less influenced by filling pressure than $\mathrm{E}$ wave velocity of mitral inflow. ${ }^{40}{ }^{41}$ Nevertheless, $E_{m}$ velocity was not better at predicting exercise capacity than conventional $\mathrm{E}$ wave velocity. In contrast, mitral annular $\mathrm{A}_{\mathrm{m}}$ velocity correlated significantly with $\mathrm{p}_{\mathrm{V}} \mathrm{O}_{2}$, whereas transmitral A velocity did not reflect exercise capacity. $A_{m}$ velocity might be a marker of left atrial function, reflecting the adaptive capacity of the left atrium to compensate for increased diastolic volume and filling pressures of the left ventricle. It is possible that effective left ventricular filling linked to preserved left atrial function is important for exercise capacity.
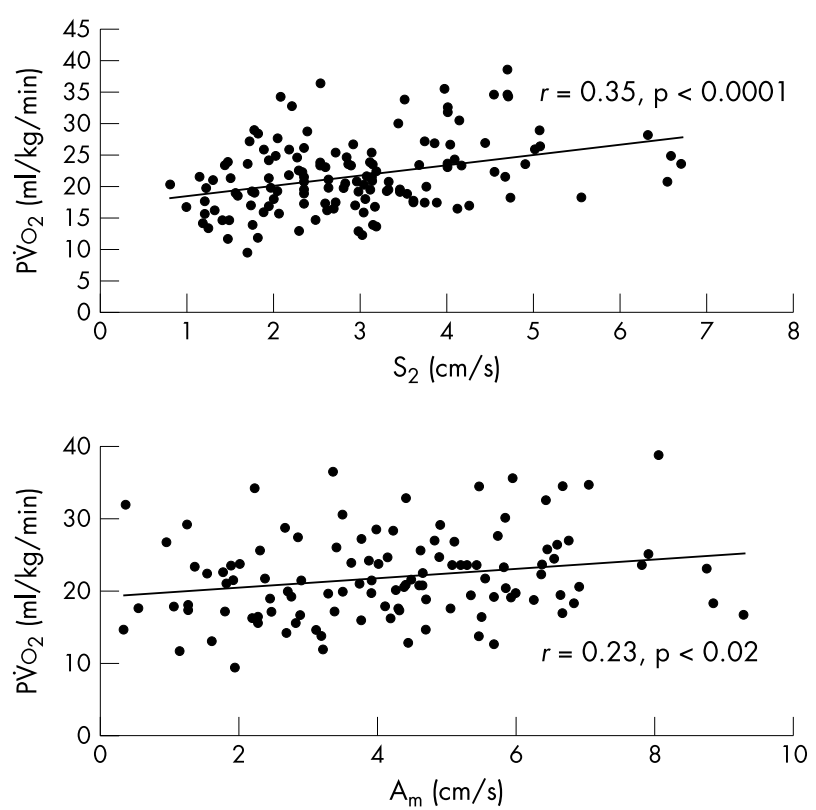

Previous data obtained invasively have suggested a role of pulmonary artery and capillary wedge pressures in predicting exercise capacity, ${ }^{42}{ }^{43}$ although not all studies have confirmed this. ${ }^{44}$ In patients with systolic and diastolic dysfunction the left atrial and pulmonary capillary wedge pressure is potentially higher than in those with only systolic dysfunction. This would support a finding that $\mathrm{E}_{\mathrm{m}}$ correlates with exercise capacity, but our data, however, suggest that a systolic index $\left(\mathrm{S}_{\mathrm{m}}\right)$ remains the most powerful correlate with exercise capacity. It is unclear why our data do not support previous results suggesting the primary role for diastolic impairment in exercise intolerance, but it is possible that our patientson high dose $\beta$ blockers and in a neutral fluid balance-may have less "diastolic" impairment than those with higher pulmonary pressures and less aggressive treatment.

Right ventricular function has been shown previously to be poorly related to exercise capacity. ${ }^{3}$ None of the right
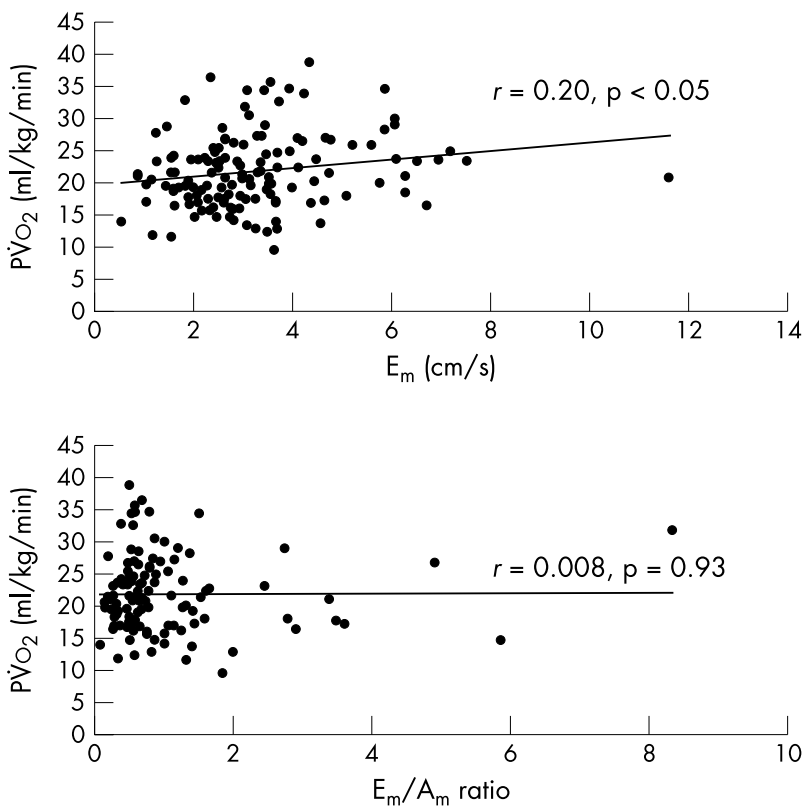

Figure 4 The relation between peak oxygen consumption and systolic and diastolic indices of longitudinal function measured by tissue Doppler imaging. 
Table 3 Regression correlations for exercise versus standard echocardiographic and TDi values

\begin{tabular}{|c|c|c|c|c|c|}
\hline & & $\mathrm{pV}_{2}$ & & $\dot{\mathrm{V}}_{\mathrm{E}} / \dot{\mathrm{V}} \mathrm{CO}_{2} \mathrm{~s}$ & \\
\hline EF (\%) & $\begin{array}{l}C \\
P\end{array}$ & $0.66^{* * *}$ & $\begin{array}{l}0.20^{\text {ns }} \\
0.21^{*}\end{array}$ & $-0.41^{* * *}$ & $\begin{array}{l}-0.25^{\mathrm{ns}} \\
-0.04^{\mathrm{ns}}\end{array}$ \\
\hline E wave $(\mathrm{cm} / \mathrm{s})$ & $\begin{array}{l}C \\
P\end{array}$ & $-0.22^{*}$ & $\begin{array}{l}0.17^{\text {ns }} \\
-0.22^{*}\end{array}$ & $0.30^{* * *}$ & $\begin{array}{l}0.05^{\text {ns }} \\
0.26^{* *}\end{array}$ \\
\hline A wave $(\mathrm{cm} / \mathrm{s})$ & $\begin{array}{l}C \\
P\end{array}$ & $0.08^{\text {ns }}$ & $\begin{array}{r}-0.26^{\mathrm{ns}} \\
0.09^{\mathrm{ns}}\end{array}$ & $0.26^{* *}$ & $\begin{array}{l}-0.01^{\mathrm{ns}} \\
-0.26^{*}\end{array}$ \\
\hline $\mathrm{E} / \mathrm{A}$ ratio & $\begin{array}{l}C \\
P\end{array}$ & $-0.25^{* *}$ & $\begin{array}{r}0.30^{*} \\
-0.20^{*}\end{array}$ & $0.38^{* * *}$ & $\begin{array}{l}0.01^{\text {ns }} \\
0.32^{\text {** }}\end{array}$ \\
\hline DT (ms) & $\begin{array}{l}C \\
P\end{array}$ & $0.25^{\star *}$ & $\begin{array}{c}-0.14^{\mathrm{ns}} \\
0.17^{*}\end{array}$ & $0.31^{* * *}$ & $\begin{array}{r}0.13^{\text {ns }} \\
-0.25^{*}\end{array}$ \\
\hline $\begin{array}{l}\text { Left ventricle } \\
\mathrm{S}_{\mathrm{m}}(\mathrm{cm} / \mathrm{s})\end{array}$ & $\begin{array}{l}C \\
P\end{array}$ & $0.67^{\star \star *}$ & $\begin{array}{l}0.5^{\star *} \\
0.35^{\star * *}\end{array}$ & $-0.51^{* * *}$ & $\begin{array}{l}-0.36^{*} \\
-0.34^{\star * *}\end{array}$ \\
\hline$E_{m}(\mathrm{~cm} / \mathrm{s})$ & $\begin{array}{l}C \\
P\end{array}$ & $0.67^{* * *}$ & $\begin{array}{l}0.51^{\star * *} \\
0.20^{*}\end{array}$ & $-0.31^{\star * *}$ & $\begin{array}{l}-0.24^{\mathrm{ns}} \\
-0.11^{\mathrm{ns}}\end{array}$ \\
\hline$A_{m}(\mathrm{~cm} / \mathrm{s})$ & $\begin{array}{l}C \\
P\end{array}$ & $0.72^{\star \star *}$ & $\begin{array}{l}0.27^{\text {ns }} \\
0.23^{*}\end{array}$ & $-0.51^{\star * *}$ & $\begin{array}{l}-0.33^{*} \\
-0.35^{* * *}\end{array}$ \\
\hline$E_{m} / A_{m}$ & $\begin{array}{l}C \\
P\end{array}$ & $-0.02^{\text {ns }}$ & $\begin{array}{l}0.35^{*} \\
0.01^{\text {ns }}\end{array}$ & $0.21^{*}$ & $\begin{array}{c}-0.09^{\text {ns }} \\
0.19^{*}\end{array}$ \\
\hline$E / E_{m}$ & $\begin{array}{l}C \\
P\end{array}$ & $-0.58^{\star \star \star}$ & $\begin{array}{l}-0.47^{* *} \\
-0.27^{* *}\end{array}$ & $0.34^{* * *}$ & $\begin{array}{l}0.27^{\text {ns }} \\
0.20^{*}\end{array}$ \\
\hline $\mathrm{A} / \mathrm{A}_{\mathrm{m}}$ & $\begin{array}{l}C \\
P\end{array}$ & $-0.36^{* * *}$ & $\begin{array}{l}-0.35^{*} \\
-0.02^{\text {ns }}\end{array}$ & $0.28^{* *}$ & $\begin{array}{l}0.27^{\text {ns }} \\
0.17^{\text {ns }}\end{array}$ \\
\hline $\begin{array}{l}\text { Right ventricle } \\
\mathrm{S}_{\mathrm{m}}(\mathrm{cm} / \mathrm{s})\end{array}$ & $\begin{array}{l}C \\
P\end{array}$ & $0.39^{* * *}$ & $\begin{array}{l}0.04^{\mathrm{ns}} \\
0.12^{\mathrm{ns}}\end{array}$ & $-0.31^{* * *}$ & $\begin{array}{l}-0.13^{\text {ns }} \\
-0.19^{*}\end{array}$ \\
\hline$E_{m}(\mathrm{~cm} / \mathrm{s})$ & $\begin{array}{l}C \\
P\end{array}$ & $-0.47^{* * *}$ & $\begin{array}{l}0.07^{\text {ns }} \\
0.02^{\text {ns }}\end{array}$ & $0.26^{* *}$ & $\begin{array}{r}-0.08^{\text {ns }} \\
0.03^{\text {ns }}\end{array}$ \\
\hline$A_{m}(\mathrm{~cm} / \mathrm{s})$ & $\begin{array}{l}C \\
P\end{array}$ & $-0.11^{\mathrm{ns}}$ & $\begin{array}{l}0.36^{*} \\
0.02^{\text {ns }}\end{array}$ & $-0.04^{\mathrm{ns}}$ & $\begin{array}{c}0.07^{\text {ns }} \\
-0.17^{*}\end{array}$ \\
\hline$E_{m} / A_{m}$ & $\begin{array}{l}C \\
P\end{array}$ & $0.54^{* * *}$ & $\begin{array}{l}-0.11^{\mathrm{ns}} \\
-0.15^{\mathrm{ns}}\end{array}$ & $-0.26^{*}$ & $\begin{array}{c}-0.27^{\text {ns }} \\
0.23^{*}\end{array}$ \\
\hline$E / E_{m}$ & $\begin{array}{l}C \\
P\end{array}$ & $-0.34^{\star \star *}$ & $\begin{array}{r}0.24^{\text {ns }} \\
-0.09^{\text {ns }}\end{array}$ & $0.28^{* *}$ & $\begin{array}{l}0.08^{\text {ns }} \\
0.09^{\text {ns }}\end{array}$ \\
\hline $\mathrm{A} / \mathrm{A}_{\mathrm{m}}$ & $\begin{array}{l}C \\
P\end{array}$ & $-0.14^{*}$ & $\begin{array}{l}-0.08^{\text {ns }} \\
-0.18^{\text {ns }}\end{array}$ & $0.11^{\mathrm{ns}}$ & $\begin{array}{r}-0.17^{\text {ns }} \\
0.27^{\text {** }}\end{array}$ \\
\hline
\end{tabular}

ventricular TDi variables correlated significantly with markers of exercise capacity or distinguished between patients in different symptomatic classes.

We have shown that TDi, which allows more detailed examination of left ventricular diastolic and systolic function, is still only weakly related to exercise tolerance. Furthermore, interventions aimed at improving LVEF have been unsuccessful in improving exercise capacity. ${ }^{45-47}$ These observations suggest that cardiac function might not be the major influence on symptoms in chronic heart failure. ${ }^{2}$

\section{Conclusions}

Our study shows that indices of longitudinal left ventricular function measured by TDi correlate more closely with peak oxygen consumption than LVEF. It also confirms previous data using other imaging techniques showing that right ventricular function is unrelated to exercise capacity.

\section{Authors' affiliations}

K K A Witte, N P Nikitin, R De Silva, J G F Cleland, A L Clark, Academic Cardiology, Castle Hill Hospital, Hull, UK

\section{REFERENCES}

1 Clark AL, Sparrow JL, Coats AJS. Muscle fatigue and dyspnoea in chronic heart failure: two sides of the same coin? Eur Heart J 1995;16:49-52.

2 Clark AL, Poole-Wilson PA, Coats AJS. Exercise limitation in chronic heart failure: central role of the periphery. J Am Coll Cardiol 1996;28:1092-102.
3 Clark AL, Swan JW, Laney R, et al. The role of right and left ventricular function in the ventilatory response to exercise in chronic heart failure. Circulation 1994;89:2062-9.

4 Chandrashekhar Y, Anand IS. Relation between major indices of prognosis in patients with chronic congestive heart failure: studies of maximal exercise oxygen consumption, neurohormones and ventricular function. Indian Heart $J$ 1992;44:213-16.

5 Carell ES, Murali S, Schulman DS, et al. Maximal exercise tolerance in chronic congestive heart failure. Relationship to resting left ventricular function. Chest 1994; 106:1746-52.

6 Davies SW, Fussell AL, Jordan SL, et al. Abnormal diastolic filling patterns in chronic heart failure-relationship to exercise capacity. Eur Heart J 1992;13:749-57.

7 Higginbotham MB, Morris KG, Conn EH, et al. Determinants of variable exercise performance among patients with severe left ventricular dysfunction. Am J Cardiol 1983;51:52-60.

8 Benge W, Litchfield RL, Marcus ML. Exercise capacity in patients with severe left ventricular dysfunction. Circulation 1980;61:955-9.

9 Weber KT, Kinasewitz GT, Janicki JS, et al. Oxygen utilisation and ventilation during exercise in patients with chronic cardiac failure. Circulation 1982;65:1212-23.

10 Franciosa JA, Park M, Levine TB. Lack of correlation between exercise capacity and indexes of restring ventricular performance in heart failure. Am J Cardiol 1981;47:33-9.

11 Cleland JG. A personal approach to identify and characterise diastolic heart failure in routine clinical practice. Rev Port Cardiol 1999;18(suppl 5):V37-9.

12 Tabet JY, Logeart D, Geyer C, et al. Comparison of the prognostic value of left ventricular filling and peak oxygen uptake in patients with systolic heart failure. Eur Heart J 2000;21:1864-71.

13 Lapu-Bula R, Robert A, De Kock M, et al. Relation of exercise capacity to left ventricular systolic function and diastolic filling in idiopathic or ischemic dilated cardiomyopathy. Am J Cardiol 1999;83:728-34.

14 Parthenakis FI, Kanoupakis EM, Kochiadakis GE, et al. Left ventricular diastolic filling pattern predicts cardiopulmonary determinants of functional capacity in patients with congestive heart failure. Am Heart $J$ 2000; 140:338-44 
15 Isaaz K. What are we actually measuring by Doppler tissue imaging? J Am Coll Cardiol 2000;36:897-9.

16 Sohn DW, Chai IH, Lee DJ, et al. Assessment of mitral annulus velocity by Doppler tissue imaging in the evaluation of left ventricular diastolic function. J Am Coll Cardiol 1997:30:474-80.

17 Caso P, D'Andrea A, Galderisi M, et al. Pulsed Doppler tissue imaging in endurance athletes: relation between left ventricular preload and myocardial regional diastolic function. Am J Cardiol 2000;85:1131-6.

18 Meluzin J, Spiranova L, Bakala J, et al. Pulsed Doppler tissue imaging of the velocity of tricuspid annular systolic motion; a new, rapid, and non-invasive method of evaluating right ventricular systolic function. Eur Heart $J$ $2001 ; 22: 340-8$.

19 Borg G. Subjective effort and physical activities. Scand J Rehabil Med 1978;6:108-13.

20 Nikitin NP, Witte KKA, Thackray SDR, et al. Longitudinal ventricular function Normal values of atrioventricular annular and myocardial velocities measured with color tissue Doppler imaging. J Am Soc Echocardiogr 2003;16:906-21.

21 Alam M, Hoglund C, Thorstrand C. Longitudinal systolic shortening of the left ventricle: an echocardiographic study in subjects with and without preserved global function. Clin Physiol 1992;12:443-52.

22 Nagueh SF, Middleton KJ, Kopelen HA, et al. Doppler tissue imaging: a noninvasive technique for evaluation of left ventricular relaxation and estimation of filling pressures. J Am Coll Cardiol 1997;30:1527-33.

23 Alam M, Hoglund C, Thorstrand C, et al. Haemodynamic significance of the atrioventricular plane displacement in patients with coronary artery disease. Eur Heart J 1992;13:194-200.

24 Pai RG, Bodenheimer MM, Pai SM, et al. Usefulness of systolic excursion of the mitral annulus as an index of left ventricular systolic function. Am J Cardiol 1991:67:222-4.

25 Alam M, Hoglund C, Thorstrand C, et al. Atrioventricular plane displacement in severe congestive heart failure following dilated cardiomyopathy or myocardial infarction. J Intern Med 1990;228:569-75.

26 Emilsson K, Alam M, Wandt B. The relation between mitral annulus motion and ejection fraction: A nonlinear function. J Am Soc Echocardiogr 2000;13:896-901.

27 Gorcsan J, Strum DP, Mandarino WA, et al. Quantitative assessment of alterations in regional left ventricular contractility with color-coded tissue Doppler echocardiography. Comparison with sonomicrometry and pressurevolume relations. Circulation 1997;95:2423-33.

28 Gulati VK, Katz WE, Follansbee WP, et al. Mitral annular descent velocity by tissue Doppler echocardiography as an index of global left ventricular function. Am J Cardiol 1996:77:979-84.

29 Miyatake K, Yamagishi M, Tanaka N, et al. New method for evaluating left ventricular wall motion by color-coded tissue Doppler imaging: in vitro and in vivo studies. J Am Coll Cardiol 1995;25:717-24

30 Yamada H, Oki T, Tabata T, et al. Assessment of left ventricular systolic wall motion velocity with pulsed tissue Doppler imaging: comparison with peak $\mathrm{dP} / \mathrm{dt}$ of the left ventricular pressure curve. J Am Soc Echocardiogr 1998;11:442-9.

31 Oki T, Fukuda K, Tabata T, et al. Effect of an acute increase in afterload on left ventricular regional wall motion velocity in healthy subjects. J Am Soc Echocardiogr 1999;12:476-83.
32 Fukuda K, Oki T, Tabata T, et al. Regional left ventricular wall motion abnormalities in myocardial infarction and mitral annular descent velocities studied with pulsed tissue Doppler imaging. J Am Soc Echocardiogr 1998;11:841-8.

33 Oki T, luchi A, Tabata $T$, et al. Left ventricular systolic wall motion velocities along the long and short axes measured by pulsed tissue Doppler imaging in patients with atrial fibrillation. J Am Soc Echocardiogr 1999; 12:121-8.

34 Oki T, Tabata T, Yamada $\mathrm{H}$, et al. Difference in systolic motion velocity of the left ventricular posterior wall in patients with asymmetric septal hypertrophy and prior anteroseptal myocardial infarction. Evaluation by pulsed tissue Doppler imaging. Jpn Heart J 1998;39:163-72.

35 Vinereanu D, Khokhar A, Fraser AG. Reproducibility of pulsed wave tissue Doppler echocardiography. J Am Soc Echocardiogr 1999;12:492-9.

36 Nikitin NP, Witte KKA, Clark AL, et al. Color tissue Doppler-derived long-axis ventricular function in heart failure with preserved global systolic function. Am J Cardiol 2002;90:1174-7.

37 Vinereanu D, Florescu N, Sculthorpe N, et al. Differentiation between pathologic and physiologic left ventricular hypertrophy by tissue Doppler assessment of long-axis function in patients with hypertrophic cardiomyopathy or systemic hypertension and in athletes. Am J Cardiol 2001;88:53-8.

38 Severino S, Caso P, Galderisi M, et al. Use of pulsed Doppler tissue imaging to assess regional left ventricular diastolic dysfunction in hypertrophic cardiomyopathy. Am J Cardiol 1998;82:1394-8.

39 Bolognesi R, Tsialtas $\mathrm{D}$, Barilli AL, et al. Detection of early abnormalities of left ventricular function by hemodynamic, echo-tissue Doppler imaging, and mitral Doppler flow techniques in patients with coronary artery disease and normal ejection fraction. J Am Soc Echocardiogr 2001; 14:764-72.

40 Sohn DW, Chai IH, Lee DJ, et al. Assessment of mitral annulus velocity by Doppler tissue imaging in the evaluation of left ventricular diastolic function. J Am Coll Cardiol 1997;30:474-80.

41 Nagueh SF, Middleton KJ, Kopelen HA, et al. Doppler tissue imaging: a noninvasive technique for evaluation of left ventricular relaxation and estimation of filling pressures. J Am Coll Cardiol 1997;30:1527-33.

42 Franciosa JA, Baker BJ, Seth L. Pulmonary versus systemic haemodynamics in determining exercise capacity of patients with chronic left ventricular failure. Am Heart J 1985; 1 10:807-13.

43 Szlachcic J, Massie BM, Kramer BL, et al. Correlates and prognostic implication of exercise capacity in chronic congestive heart failure. Am J Cardiol 1985;55:1037-10.

44 Gibbs JSR, Keegan J, Wright C, et al. Pulmonary artery pressure changes during exercise and daily activities in chronic heart failure. J Am Coll Cardiol 1990;15:52-61.

45 Packer M, Bristow MR, Cohn JN, et al. The effect of carvedilol on morbidity and mortality in patients with chronic heart failure. N Engl J Med 1996;334:1349-55.

46 CIBIS II Investigators. The Cardiac Insufficiency Bisoprolol Study II (CIBIS II). Lancet 1999;353:9-13.

47 Australia/New Zealand Heart Failure Research Collaborative Group. Randomised, placebo-controlled trial of carvedilol in patients with congestive heart failure due to ischaemic heart disease. Lancet 1997;349:375-80.

\section{IMAGES IN CARDIOLOGY}

\section{Mid aortic syndrome and Alagille syndrome}

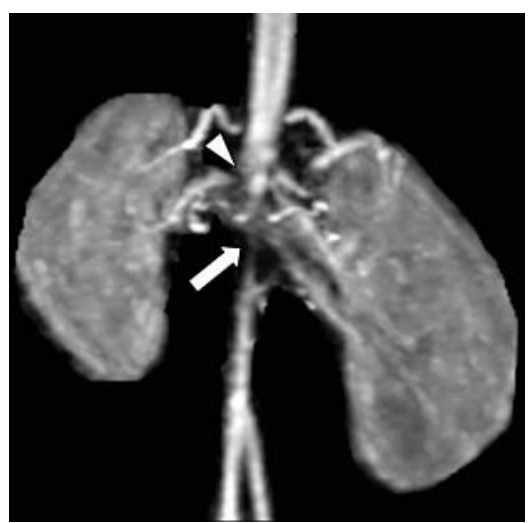

Tis is a magnetic resonance (MR) angiogram of an abdominal coarctation in a 13 year old patient with Alagille syndrome. Although her femoral pulses were weak, she was asymptomatic with no upper limb hypertension or symptoms of intermittent claudication. At cardiac catheterisation, there was a pull back gradient of $30 \mathrm{~mm} \mathrm{Hg}$ from the ascending aorta to the descending abdominal aorta. The suprarenal abdominal aorta is normal in diameter but becomes significantly narrowed for a considerable length below the level of the renal arteries. Distal to this segment, the abdominal aorta is mildly to moderately narrowed up to the bifurcation of the common iliac arteries. There is also narrowing of the proximal renal arteries bilaterally. The findings of the MR angiogram were similar to that of invasive angiography performed previously.

Infrarenal high grade abdominal aortic stenosis (arrow) demonstrated on gadolinium magnetic resonance angiogram (maximum intensity projection, coronal source images, 1.5 T GE Horizon MR Scanner). Bilateral proximal renal artery stenosis is also demonstrated (arrowhead). 